Программа “северное измерение” и интересы России

\title{
М.А. Деркач
}

ДЕРКАЧ Михаил Александрович, студент факультета истории, политологии и права Российского государственного гуманитарного университета.

За последнее десятилетие на севере Европы произошли существенные перемены, которые открыли новые перспективы для регионального и межрегионального сотрудничества. Следствием этого стал рост внимания к северной части Европы, достаточно долго находившейся на периферии международной политики, со стороны Европейского союза (ЕС), а также США, разработавших и представивших в 1997 г. собственную Североевропейскую Инициативу (СЕИ)_1 .

Вступление Финляндии в ЕС в 1995 г. означало, что российско-финляндская граница протяженностью более 1300 км стала общей для Евросоюза и России, а североевропейский регион превратился в связующее их звено. Таким образом север Европы априори приобрел особое значение в развитии сотрудничества ЕС и России [Люра 1998: 25]. “Южной и центральной Европе нужна хорошо развитая северная Европа, дабы можно было использовать ее ресурсы на развитие всего континента” [Крылов 1996: 43]. Северо-западные регионы России обладают громадным экономическим потенциалом (газоконденсатные и нефтеносные месторождения, лесные ресурсы, рудные ископаемые), более эффективное использование которого выгодно и ЕС.

Но было бы ошибочным считать, что российский северо-запад нужен Европе лишь как “сырьевой придаток”. Напротив, ЕС заинтересован в стабильном развитии сопредельных с ним регионов, а также в решении широкого круга проблем, его затрудняющих. Это касается и экономики, и социальной сферы, и экологии, и становления рыночных институтов, и преодоления разрыва в уровне развития между странами ЕС и регионами, примыкающими к новой внешней границе Евросоюза.

Все вышеперечисленное обусловило необходимость выработки новых подходов к северу Европы, выделения деятельности на этом перспективном направлении в составляющую региональной и общей политики Евросоюза, получившую название “северное измерение”.

Инициатива, как это часто случается во взаимоотношениях Евросоюза и России, исходила от Финляндии. В течение трех десятилетий эта страна была вторым по значению (после ФРГ) экономическим партнером Советского Союза в Европе. Короткий период “похолодания” в российско-финляндских связях в первые пять лет после распада СССР сменился добрососедскими взаимовыгодными отношениями [см. Аксенов 1994].

Впервые предложение о “северном измерении” политики ЕС было выдвинуто премьер-министром Финляндии П.Липпоненом в сентябре 1997 г. Страны Евросоюза весьма сдержанно отнеслись к этой смелой инициативе ввиду того, что ее реализация требовала значительных финансовых затрат из бюджета ЕС. И все-таки на сессии Совета ЕС в Люксембурге в декабре 1997 г. предложение Финляндии было “принято к сведению”, а Европейская комиссия получила поручение подготовить промежуточный отчет, через год одобренный на Венском саммите ЕС. После этого Европейская комиссия начала непосредственную разработку основополагающих положений концепции “северного измерения”, которые были утверждены в июне 1999 г. на очередной встрече глав стран ЕС в Кельне [Евро 1999: 39-43].

Наконец, в ноябре 1999 г. в Хельсинки прошла конференция министров иностранных дел стран ЕС и государств “северного измерения”, где было принято решение о регулярном проведении таких конференций для обзора хода реализации согласованных программ и проектов.

Ключевым понятием концепции “северного измерения” является “позитивная взаимозависимость”. В решении Совета ЕС от 31 мая 1999 г. подчеркивается, что ““северное измерение” может способствовать 
укреплению позитивной взаимозависимости Европейского союза, России и других государств Балтийского моря, особенно принимая во внимание процесс расширения ЕС, и тем самым обеспечить безопасность, стабильность и устойчивое развитие северной Европы” [Евро 1999: 39].

Применяя этот термин, ЕС использовал прежде всего опыт европейских стран 50-х годов прошлого века: исходной позицией Общего рынка было налаживание такого сотрудничества и взаимовлияния в экономике, такая интеграция и взаимозависимость, которые исключали бы враждебность и возникновение военных и иных конфликтов в Западной Европе. Несмотря на ряд оговорок, этого удалось добиться. Вполне логично, что сегодня европейцы стремятся внедрить указанный принцип уже в рамках “северного измерения”.

При этом, правда, существует вероятность неблагоприятных сценариев. Достаточно вспомнить, например, желание стран Балтии вступить в НАТО и крайне жесткую позицию России по этому вопросу. Взаимная непримиримость сторон фактически означает возникновение новых разделительных линий, что противоречит самой идее “северного измерения” и создает серьезные препятствия для реализации данной концепции.

Все же нельзя не отметить, что в целом задачи “северного измерения” во многом перекликаются с российским подходом к проблемам североевропейского региона - не только экономическим и экологическим, но и политическим, связанным с укреплением безопасности и стабильности [Северное измерение 1999].

Выработана общая позиция и в отношении географических рамок “северного измерения”. Согласно документам ЕС, оно условно охватывает Исландию, Скандинавию, Польшу, Финляндию, страны Балтии, северные земли Германии и северо-запад России (общая площадь территории свыше 3 млн. кв.км с населением примерно 60 млн. человек, при этом на российские регионы приходится более половины всей территории и около четверти населения).

К сожалению, приходится констатировать, что в настоящее время перечень сфер сотрудничества Евросоюза с Россией в рамках “северного измерения” не содержит ничего принципиально нового. ЕС, заинтересованный в использовании природных богатств российского северо-запада, приоритетными направлениями считает прежде всего энергетику, лесную промышленность и охрану окружающей среды.

Практически не затронуты другие вопросы, указанные в Коллективной стратегии ЕС в отношении России [Коллективная стратегия 2000: 107-121] - консолидация демократии и правовых институтов, укрепление гражданского общества в России, интеграция ее в общее европейское экономическое и социальное пространство. В итоге оказывается незадействованным российский производственный и научно-технический потенциал. Именно поэтому “для России принципиально важно, чтобы в рамках ‘северного измерения’ она рассматривалась как полноправный субъект разностороннего сотрудничества, а не только как объект обеспечения топливно-сырьевых потребностей стран ЕС” [Дерябин 2000: 65].

На мой взгляд, не стоит излишне драматизировать, особенно в свете нынешних экономических реалий, факт использования Евросоюзом в рамках “северного измерения” природных ресурсов России. Наша страна сейчас не в состоянии самостоятельно распорядиться собственным потенциалом, в то время как сотрудничество на данном направлении может привлечь в российскую экономику немалые инвестиции из Европы. Последнее обстоятельство во многом способствует поддержанию положительного сальдо в торговле с Евросоюзом, что составляет около 40\% внешнеторгового оборота России. Чрезвычайно важно, чтобы Россия сумела разумно воспользоваться поступающими средствами. Вспомним, как Финляндия и Норвегия из “сырьевых” стран превратились в индустриальные.

Кроме того, не следует забывать и о зависимости ЕС от поставок российского топлива, газа и леса, которые, вне всяких сомнений, являются действенным инструментом “привязки” интересов Евросоюза к России. В качестве примера его позитивного использования назову следующие энергетические проекты: 1) строительство североевропейского газопровода для подачи газа из России через страны Северной Европы в континентальную Европу; 2) освоение Штокмановского газоконденсатного месторождения в Баренцевом море (пятого по мощности в мире); 3) создание Балтийской нефтепроводной системы, которая объединит сеть нефтепроводов России с рынками ЕС; 4) строительство Балтийской электропередающей системы, с пуском которой образуется единый Балтийский рынок электроэнергии. Помимо этого, перспективными для России представляются транспортные проекты в Балтийском и Баренцевом/Евроарктическом регионах, а 
Важнейшее место в сотрудничестве по “северному измерению” отводится охране окружающей среды североевропейского региона. Евросоюз заинтересован в повышении безопасности находящихся на северо-западе России атомных электростанций и обеспечении здесь стабильной экологической ситуации. Надо признать, что российские власти проявляют в данном вопросе преступную небрежность. Вопреки здравому смыслу они, по словам известного финского политолога Л.Хейнинена [Верхняя Тулома 2000: 4], вместо решения экологических проблем путем внедрения новых разработок и технологий руководствуются принципом: “нет производства — нет проблем с загрязнением окружающей среды”. Такая позиция российских чиновников, а также непомерные таможенные поборы и налоговая система “византийских времен” делают практически нереальными перспективы создания совместных предприятий.

В рамках “северного измерения” активно работает ряд программ по обеспечению безопасности, предусматривающих расширение сотрудничества в борьбе с организованной преступностью, контрабандой наркотиков и ядерных материалов, нелегальной иммиграцией, отмыванием денег.

Итак, что же нового дает России “северное измерение”? Конечно, сотрудничество в указанных направлениях развивалось и раньше, но еще никогда взаимодействие ЕС с Россией и другими странами региона не выделялось в особое направление политики Евросоюза. Это, по существу, означает признание со стороны ЕС особой значимости североевропейского региона для развития всей Европы.

Однако необходимо сделать несколько оговорок. Во-первых, рассматривая все существующие и возможные направления сотрудничества в едином комплексе, ЕС в качестве приоритета выделяет рационализацию, оптимизацию программ и проектов, обеспечение согласованных действий в рамках общей политики Союза. Подразумевается, что ЕС берет на себя роль координатора проектов при их практической реализации, а значит, почти исключается возможность создания новых институтов и инструментов для воплощения в жизнь концепции “северного измерения”. Во-вторых, не предусмотрено выделение Евросоюзом из своего бюджета дополнительных средств по существующим программам и проектам - речь может идти лишь о перераспределении и более эффективном использовании уже имеющихся ассигнований. Идея состоит в том, чтобы сотрудничество шло за счет заинтересованных государств и частных инвестиций.

Предварительные расчеты показывают, что для реализации намеченных на $2000-2020$ гг. проектов потребуется как минимум 82 млрд. экю, причем 45\% этой суммы должно быть инвестировано в нефтегазовый сектор, $15 \%$ - на обеспечение радиационной безопасности и охрану окружающей среды, $9 \%$ в электроэнергетику, 8\% - в лесное хозяйство, 5\% - в горнорудную промышленность и 8\% - в развитие транспорта. Предполагается, что около 40\% расходов будет покрыто через коммерческие займы и частные инвестиции, а международные финансовые институты выделят примерно 25 млрд. экю. Для реализации программы возможно более активное привлечение Всемирного банка, Европейского инвестиционного банка, Европейского банка реконструкции и развития, Скандинавского инвестиционного банка и Балтийской региональной программы ОЕСР. Еще около трети от суммы предполагаемых расходов организаторы “северного измерения” рассчитывают получить за счет национального финансирования проектов странами-участницами [The Ministry 1998: 66-67].

Финансирование российской части “северного измерения” ведется главным образом по программе ТАСИС. В ее рамках к настоящему времени получили поддержку более 150 проектов общей стоимостью свыше 250 млн. экю [Дружинин 2000: 104]. Кроме того, принято решение об увеличении ассигнований на обеспечение приграничного сотрудничества с 10 до 25\% годового бюджета ТАСИС. Другой важный инструмент ЕС программа ИНТЕРРЕГ, которая постепенно включается в финансирование проектов в регионах Балтийского и Баренцева морей.

Стоит также обратить внимание на ту роль, которая отводится существующим на севере Европы региональным организациям - Совету государств Балтийского моря (СГБМ) и Совету Баренцева/Евроарктического региона (СБЕР) [Успенский, Комиссаров 1992; Воронов 1994]. С продвижением программы “северное измерение” их значение должно существенно возрасти. Так произошло, в частности, с созданным в 1996 г. для содействия улучшению условий жизни малочисленных народов Севера и сохранения их идентичности Арктическим советом (в него входят Канада, Дания, Исландия, Норвегия, Швеция, Россия и Комиссия ЕС) в связи с разработкой концепции “северного измерения” в таких областях, как охрана окружающей среды, устойчивое развитие и исследование Арктики. 
Можно было бы использовать и многолетний опыт Северного совета (консультативный орган сотрудничества между парламентами и правительствами Дании, Исландии, Норвегии, Швеции и Финляндии).

Еще одним элементом реализации концепции “северного измерения” должно стать дальнейшее развитие двусторонних связей стран северной Европы и сотрудничества в сопредельных районах. Для российской стороны наиболее перспективным здесь представляется российско-финляндское взаимодействие на основе соглашения между правительствами России и Финляндии о сотрудничестве в Мурманской области, Республике Карелия, Санкт-Петербурге и Ленинградской области от 20 января 1992 г.

Заметное место в отношениях Финляндии с соседними российскими регионами занимает выделение средств из государственного бюджета страны на финансирование проектов на северо-западе России. Прежде всего это касается Республики Карелия, двусторонние связи с которой развиваются наиболее успешно: в 1992 1998 гг. в Карелии осуществлялись или находились в стадии разработки порядка 250 совместных проектов, предусматривавших “взаимодействие в сфере передачи новых технологий, предоставление технической помощи, а также ноу-хау” [Романов 1998: 34]. Примечательно, что для проектов, которые поддерживаются — полностью или частично — финским бюджетом, российская сторона предоставляет специальные таможенные льготы. Вполне возможно и использование в контексте “северного измерения” различного рода межгосударственных соглашений о сотрудничестве в североевропейском регионе.

Наивно полагать, что реализация рассматриваемой концепции состоит лишь в выделении средств, координации деятельностии обеспечении эффективности существующих структур и программ. Очевидно, что необходимы дополнительные шаги с целью создания благоприятных условий для совместной деятельности. Поскольку “северное измерение” и его перспективы напрямую увязываются с расширением $\mathrm{EC}$, развитие сотрудничества во многом будет зависеть от устранения барьеров и дискриминационных ограничений в торгово-экономической области. Интересы России здесь заключаются в том, чтобы минимизировать свои экономические убытки.

Сотрудничество в рамках концепции следует поднять на уровень федеральной политики. При определении приоритетности отдельных направлений и проектов “северного измерения” необходимо отстаивать хозяйственные, социальные и иные потребности как российских северо-западных регионов, так и страны в целом. Чем полнее концепция и согласованные проекты отразят эти потребности, тем активнее и объемнее будет участие России в “северном измерении”.

Одной из наиболее острых проблем во взаимоотношениях России с ЕС является статус Калининградской области, которая после вступления Литвы и Польши в ЕС фактически станет российским анклавом внутри Евросоюза. Кстати, это вызов не только России, но и самому Евросоюзу. Только принятие эффективных согласованных мер поможет избежать негативных последствий для приграничных связей области, ее транзитного сообщения с Россией и, как следствие - для ее экономической и социальной ситуации.

Такие опасения не в полной мере разделяют на Западе. Министр иностранных дел Финляндии полагает, что “Калининград из российского анклава превращается в известном смысле в европейский анклав, а Балтийское море становится внутренним европейским морем с чрезвычайно динамичными перспективами развития торговли и сотрудничества” [см. Нюберг 2000]. Некоторые позитивные решения проблемы Калининградской области намечены, например, в совместном российско-литовском проекте, предложенном Евросоюзу в феврале 2000 г.

Мне представляется, что жизнеспособность и перспективность концепции “северного измерения” и принципа “позитивной взаимозависимости” напрямую связаны с тем, насколько ЕС и входящие в него государства в дальнейшем будут учитывать законные интересы России, равно как и с тем, насколько она сама готова идти на разумные уступки.

Еще одна важная проблема России - отсутствие четкого разграничения компетенции, в т.ч. в области внешнеэкономических связей и международного сотрудничества, между федеральным центром и субъектами Федерации [Авдеев 2000: 93]. К сожалению, этот вопрос пока остается неразрешенным в российском законодательстве. А ведь именно регионам должна принадлежать особая роль в реализации “северного измерения”. 
В этой ситуации первостепенное значение приобретают законы “О правовом статусе приграничных территорий” (с 1996 г. находящийся на рассмотрении Федерального Собрания) и “Об общих принципах трансграничного субрегионального сотрудничества с участием субъектов Российской Федерации” (который еще предстоит разработать). Важную роль призван сыграть и закон “О координации международных и внешнеэкономических связей субъектов Российской Федерации”, вступивший в силу в январе 1999 г. [Дерябин 2000: 70].

В России нет также правовой базы для выработки единой концепции трансграничного субрегионального сотрудничества, которое приобретает все больший размах (особенно это касается Карелии, имеющей общую границу с Евросоюзом). В 1999 г. правительство Республики Карелия совместно с властями трех приграничных областей восточной Финляндии выдвинуло идею создания “еврорегиона 'Карелия”, которая может быть использована Россией для реализации проекта “северного измерения”. Осуществление этой идеи способно открыть перспективные формы взаимодействия сопредельных территорий на внешних границах РФ и ЕС [Шлямин 1999: 30-32].

Стоит вспомнить и о тех возможностях, которые предоставляет России участие в Европейской рамочной конвенции о приграничном сотрудничестве территориальных сообществ и властей, являющейся в настоящее время основополагающим международно-правовым актом в области субрегионального сотрудничества. К сожалению, протокол о присоединении страны к этой конвенции до сих пор не ратифицирован.

Появление и быстрое развитие концепции “северного измерения” самым активным образом способствуют укреплению внешних связей ЕС в северной Европе, привносят новые элементы в его внешнюю политику и политику безопасности. Очевидна связь данной концепции с процессами в самом ЕС, с планами по его расширению, а также с его структурной, экономической, социальной и другой политикой. В настоящее время представляется несомненным, что “северное измерение” как часть общеевропейской политики придется учитывать при принятии решений в различных областях.

Некоторая, иногда излишняя осторожность Евросоюза в отношении России связана в основном с опасениями, что та “не сумеет откликнуться на открывающиеся перед ней возможности и будет все больше изолироваться вне рамок европейского развития” [см. Нюберг 2000]. “Северное измерение” дает нашей стране великолепный шанс постепенно интегрироваться в объединенное европейское пространство, но только от нее самой зависит, насколько успешным будет этот процесс.

Авдеев А.А. 2000. Международные и внешнеэкономические связи российских регионов. - Международная жизнь, № 4.

Аксенов М. 1994. Финляндия — наш традиционный торговый партнер. - Экономика и жизнь, № 27.

Верхняя Тулома как зеркало России. 2000. - За рубежом, № 7.

Воронов К.В. 1994. Россия и Северная Европа: новые ориентиры. - Мировая политика и международные отношения, № 1.

Дерябин Ю. 2000. Северное измерение и интерес России. - Современная Европа, № 2.

Дружинин П. 2000. Республика Карелия как пограничный и периферийный регион. - VI world congress. Tampere, 29.07 - 3.08. Abstracts.

Евро. 1999. № 11.

Коллективная стратегия ЕС в отношении России. 2000. - Современная Европа, № 1.

Крылов С.Б. 1996. Сотрудничество на Севере Европы. - Международная жизнь, № 9.

Люра М. 1998. Россия и Финляндия: партнеры в Новой Северной Европе. - Новое время, № 46.

Нюберг Р. 2000. Речь на 116-ой Конференции Бергердорфского форума. - Международная жизнь, № 4.

Романов С.Л. 1998. Межрегиональное сотрудничество на севере Европы. - Международная жизнь, № 3. 
Северное измерение России полезно. 1999. - Парламентская газета, 29.01.

Успенский Н.Н., Комиссаров С.Д. 1992. Новая страница сотрудничества в регионе Балтии (К началу деятельности Совета государств Балтийского моря). - Международная жизнь, № 11/12.

Шлямин В.Н. 1999. Растет роль субрегионального фактора на севере Европы. - Евро, № 12.

The Ministry for Foreign Affairs. Northern Dimension. Working Paper. 1998. Helsinki.

___ СЕИ предусматривает укрепление отношений США со странами Скандинавии, Балтии и северо-западными регионами России. В рамках этой программы определены шесть приоритетных направлений: развитие предпринимательства, сотрудничество правоохранительных органов, содействие созданию гражданского общества, энергетика, в т.ч. безопасность АЭС, экология и здравоохранение. 


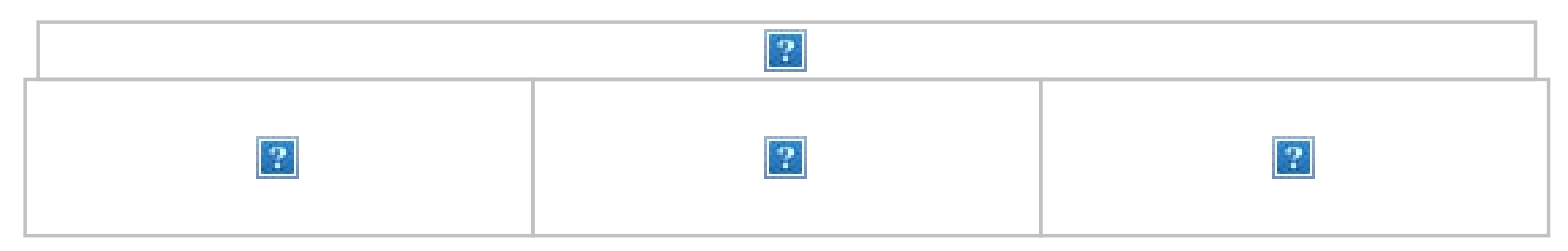

Программа “северное измерение” и интересы России

\section{М.А. Деркач}

ДЕРКАЧ Михаил Александрович, студент факультета истории, политологии и права Российского государственного гуманитарного университета.

За последнее десятилетие на севере Европы произошли существенные перемены, которые открыли новые перспективы для регионального и межрегионального сотрудничества. Следствием этого стал рост внимания к северной части Европы, достаточно долго находившейся на периферии международной политики, со стороны Европейского союза (ЕС), а также США, разработавших и представивших в 1997 г. собственную Североевропейскую Инициативу (СЕИ)_1 1 .

Вступление Финляндии в ЕС в 1995 г. означало, что российско-финляндская граница протяженностью более 1300 км стала общей для Евросоюза и России, а североевропейский регион превратился в связующее их звено. Таким образом север Европы априори приобрел особое значение в развитии сотрудничества ЕС и России [Люра 1998: 25]. “Южной и центральной Европе нужна хорошо развитая северная Европа, дабы можно было использовать ее ресурсы на развитие всего континента” [Крылов 1996: 43]. Северо-западные регионы России обладают громадным экономическим потенциалом (газоконденсатные и нефтеносные месторождения, лесные ресурсы, рудные ископаемые), более эффективное использование которого выгодно и ЕС.

Но было бы ошибочным считать, что российский северо-запад нужен Европе лишь как “сырьевой придаток”. Напротив, ЕС заинтересован в стабильном развитии сопредельных с ним регионов, а также в решении широкого круга проблем, его затрудняющих. Это касается и экономики, и социальной сферы, и экологии, и становления рыночных институтов, и преодоления разрыва в уровне развития между странами ЕС и регионами, примыкающими к новой внешней границе Евросоюза.

Все вышеперечисленное обусловило необходимость выработки новых подходов к северу Европы, выделения деятельности на этом перспективном направлении в составляющую региональной и общей политики Евросоюза, получившую название “северное измерение”.

Инициатива, как это часто случается во взаимоотношениях Евросоюза и России, исходила от Финляндии. В течение трех десятилетий эта страна была вторым по значению (после ФРГ) экономическим партнером Советского Союза в Европе. Короткий период “похолодания” в российско-финляндских связях в первые пять лет после распада СССР сменился добрососедскими взаимовыгодными отношениями [см. Аксенов 1994].

Впервые предложение о “северном измерении” политики ЕС было выдвинуто премьер-министром Финляндии П.Липпоненом в сентябре 1997 г. Страны Евросоюза весьма сдержанно отнеслись к этой смелой инициативе ввиду того, что ее реализация требовала значительных финансовых затрат из бюджета ЕС. И все-таки на сессии Совета ЕС в Люксембурге в декабре 1997 г. предложение Финляндии было “принято к сведению”, а Европейская комиссия получила поручение подготовить промежуточный отчет, через год одобренный на Венском саммите ЕС. После этого Европейская комиссия начала непосредственную разработку основополагающих положений концепции “северного измерения”, которые были утверждены в июне 1999 г. на очередной встрече глав стран ЕС в Кельне [Евро 1999: 39-43].

Наконец, в ноябре 1999 г. в Хельсинки прошла конференция министров иностранных дел стран ЕС и государств “северного измерения”, где было принято решение о регулярном проведении таких конференций для обзора хода реализации согласованных программ и проектов.

Ключевым понятием концепции “северного измерения” является “позитивная взаимозависимость”. В решении Совета ЕС от 31 мая 1999 г. подчеркивается, что ““северное измерение” может способствовать 
укреплению позитивной взаимозависимости Европейского союза, России и других государств Балтийского моря, особенно принимая во внимание процесс расширения ЕС, и тем самым обеспечить безопасность, стабильность и устойчивое развитие северной Европы” [Евро 1999: 39].

Применяя этот термин, ЕС использовал прежде всего опыт европейских стран 50-х годов прошлого века: исходной позицией Общего рынка было налаживание такого сотрудничества и взаимовлияния в экономике, такая интеграция и взаимозависимость, которые исключали бы враждебность и возникновение военных и иных конфликтов в Западной Европе. Несмотря на ряд оговорок, этого удалось добиться. Вполне логично, что сегодня европейцы стремятся внедрить указанный принцип уже в рамках “северного измерения”.

При этом, правда, существует вероятность неблагоприятных сценариев. Достаточно вспомнить, например, желание стран Балтии вступить в НАТО и крайне жесткую позицию России по этому вопросу. Взаимная непримиримость сторон фактически означает возникновение новых разделительных линий, что противоречит самой идее “северного измерения” и создает серьезные препятствия для реализации данной концепции.

Все же нельзя не отметить, что в целом задачи “северного измерения” во многом перекликаются с российским подходом к проблемам североевропейского региона - не только экономическим и экологическим, но и политическим, связанным с укреплением безопасности и стабильности [Северное измерение 1999].

Выработана общая позиция и в отношении географических рамок “северного измерения”. Согласно документам ЕС, оно условно охватывает Исландию, Скандинавию, Польшу, Финляндию, страны Балтии, северные земли Германии и северо-запад России (общая площадь территории свыше 3 млн. кв.км с населением примерно 60 млн. человек, при этом на российские регионы приходится более половины всей территории и около четверти населения).

К сожалению, приходится констатировать, что в настоящее время перечень сфер сотрудничества Евросоюза с Россией в рамках “северного измерения” не содержит ничего принципиально нового. ЕС, заинтересованный в использовании природных богатств российского северо-запада, приоритетными направлениями считает прежде всего энергетику, лесную промышленность и охрану окружающей среды.

Практически не затронуты другие вопросы, указанные в Коллективной стратегии ЕС в отношении России [Коллективная стратегия 2000: 107-121] - консолидация демократии и правовых институтов, укрепление гражданского общества в России, интеграция ее в общее европейское экономическое и социальное пространство. В итоге оказывается незадействованным российский производственный и научно-технический потенциал. Именно поэтому “для России принципиально важно, чтобы в рамках ‘северного измерения’ она рассматривалась как полноправный субъект разностороннего сотрудничества, а не только как объект обеспечения топливно-сырьевых потребностей стран ЕС” [Дерябин 2000: 65].

На мой взгляд, не стоит излишне драматизировать, особенно в свете нынешних экономических реалий, факт использования Евросоюзом в рамках “северного измерения” природных ресурсов России. Наша страна сейчас не в состоянии самостоятельно распорядиться собственным потенциалом, в то время как сотрудничество на данном направлении может привлечь в российскую экономику немалые инвестиции из Европы. Последнее обстоятельство во многом способствует поддержанию положительного сальдо в торговле с Евросоюзом, что составляет около 40\% внешнеторгового оборота России. Чрезвычайно важно, чтобы Россия сумела разумно воспользоваться поступающими средствами. Вспомним, как Финляндия и Норвегия из “сырьевых” стран превратились в индустриальные.

Кроме того, не следует забывать и о зависимости ЕС от поставок российского топлива, газа и леса, которые, вне всяких сомнений, являются действенным инструментом “привязки” интересов Евросоюза к России. В качестве примера его позитивного использования назову следующие энергетические проекты: 1) строительство североевропейского газопровода для подачи газа из России через страны Северной Европы в континентальную Европу; 2) освоение Штокмановского газоконденсатного месторождения в Баренцевом море (пятого по мощности в мире); 3) создание Балтийской нефтепроводной системы, которая объединит сеть нефтепроводов России с рынками ЕС; 4) строительство Балтийской электропередающей системы, с пуском которой образуется единый Балтийский рынок электроэнергии. Помимо этого, перспективными для России представляются транспортные проекты в Балтийском и Баренцевом/Евроарктическом регионах, а 
Важнейшее место в сотрудничестве по “северному измерению” отводится охране окружающей среды североевропейского региона. Евросоюз заинтересован в повышении безопасности находящихся на северо-западе России атомных электростанций и обеспечении здесь стабильной экологической ситуации. Надо признать, что российские власти проявляют в данном вопросе преступную небрежность. Вопреки здравому смыслу они, по словам известного финского политолога Л.Хейнинена [Верхняя Тулома 2000: 4], вместо решения экологических проблем путем внедрения новых разработок и технологий руководствуются принципом: “нет производства — нет проблем с загрязнением окружающей среды”. Такая позиция российских чиновников, а также непомерные таможенные поборы и налоговая система “византийских времен” делают практически нереальными перспективы создания совместных предприятий.

В рамках “северного измерения” активно работает ряд программ по обеспечению безопасности, предусматривающих расширение сотрудничества в борьбе с организованной преступностью, контрабандой наркотиков и ядерных материалов, нелегальной иммиграцией, отмыванием денег.

Итак, что же нового дает России “северное измерение”? Конечно, сотрудничество в указанных направлениях развивалось и раньше, но еще никогда взаимодействие ЕС с Россией и другими странами региона не выделялось в особое направление политики Евросоюза. Это, по существу, означает признание со стороны ЕС особой значимости североевропейского региона для развития всей Европы.

Однако необходимо сделать несколько оговорок. Во-первых, рассматривая все существующие и возможные направления сотрудничества в едином комплексе, ЕС в качестве приоритета выделяет рационализацию, оптимизацию программ и проектов, обеспечение согласованных действий в рамках общей политики Союза. Подразумевается, что ЕС берет на себя роль координатора проектов при их практической реализации, а значит, почти исключается возможность создания новых институтов и инструментов для воплощения в жизнь концепции “северного измерения”. Во-вторых, не предусмотрено выделение Евросоюзом из своего бюджета дополнительных средств по существующим программам и проектам - речь может идти лишь о перераспределении и более эффективном использовании уже имеющихся ассигнований. Идея состоит в том, чтобы сотрудничество шло за счет заинтересованных государств и частных инвестиций.

Предварительные расчеты показывают, что для реализации намеченных на $2000-2020$ гг. проектов потребуется как минимум 82 млрд. экю, причем 45\% этой суммы должно быть инвестировано в нефтегазовый сектор, $15 \%$ - на обеспечение радиационной безопасности и охрану окружающей среды, $9 \%$ в электроэнергетику, 8\% - в лесное хозяйство, 5\% - в горнорудную промышленность и 8\% - в развитие транспорта. Предполагается, что около 40\% расходов будет покрыто через коммерческие займы и частные инвестиции, а международные финансовые институты выделят примерно 25 млрд. экю. Для реализации программы возможно более активное привлечение Всемирного банка, Европейского инвестиционного банка, Европейского банка реконструкции и развития, Скандинавского инвестиционного банка и Балтийской региональной программы ОЕСР. Еще около трети от суммы предполагаемых расходов организаторы “северного измерения” рассчитывают получить за счет национального финансирования проектов странами-участницами [The Ministry 1998: 66-67].

Финансирование российской части “северного измерения” ведется главным образом по программе ТАСИС. В ее рамках к настоящему времени получили поддержку более 150 проектов общей стоимостью свыше 250 млн. экю [Дружинин 2000: 104]. Кроме того, принято решение об увеличении ассигнований на обеспечение приграничного сотрудничества с 10 до 25\% годового бюджета ТАСИС. Другой важный инструмент ЕС программа ИНТЕРРЕГ, которая постепенно включается в финансирование проектов в регионах Балтийского и Баренцева морей.

Стоит также обратить внимание на ту роль, которая отводится существующим на севере Европы региональным организациям - Совету государств Балтийского моря (СГБМ) и Совету Баренцева/Евроарктического региона (СБЕР) [Успенский, Комиссаров 1992; Воронов 1994]. С продвижением программы “северное измерение” их значение должно существенно возрасти. Так произошло, в частности, с созданным в 1996 г. для содействия улучшению условий жизни малочисленных народов Севера и сохранения их идентичности Арктическим советом (в него входят Канада, Дания, Исландия, Норвегия, Швеция, Россия и Комиссия ЕС) в связи с разработкой концепции “северного измерения” в таких областях, как охрана окружающей среды, устойчивое развитие и исследование Арктики. 
Можно было бы использовать и многолетний опыт Северного совета (консультативный орган сотрудничества между парламентами и правительствами Дании, Исландии, Норвегии, Швеции и Финляндии).

Еще одним элементом реализации концепции “северного измерения” должно стать дальнейшее развитие двусторонних связей стран северной Европы и сотрудничества в сопредельных районах. Для российской стороны наиболее перспективным здесь представляется российско-финляндское взаимодействие на основе соглашения между правительствами России и Финляндии о сотрудничестве в Мурманской области, Республике Карелия, Санкт-Петербурге и Ленинградской области от 20 января 1992 г.

Заметное место в отношениях Финляндии с соседними российскими регионами занимает выделение средств из государственного бюджета страны на финансирование проектов на северо-западе России. Прежде всего это касается Республики Карелия, двусторонние связи с которой развиваются наиболее успешно: в 1992 1998 гг. в Карелии осуществлялись или находились в стадии разработки порядка 250 совместных проектов, предусматривавших “взаимодействие в сфере передачи новых технологий, предоставление технической помощи, а также ноу-хау” [Романов 1998: 34]. Примечательно, что для проектов, которые поддерживаются — полностью или частично — финским бюджетом, российская сторона предоставляет специальные таможенные льготы. Вполне возможно и использование в контексте “северного измерения” различного рода межгосударственных соглашений о сотрудничестве в североевропейском регионе.

Наивно полагать, что реализация рассматриваемой концепции состоит лишь в выделении средств, координации деятельностии обеспечении эффективности существующих структур и программ. Очевидно, что необходимы дополнительные шаги с целью создания благоприятных условий для совместной деятельности. Поскольку “северное измерение” и его перспективы напрямую увязываются с расширением $\mathrm{EC}$, развитие сотрудничества во многом будет зависеть от устранения барьеров и дискриминационных ограничений в торгово-экономической области. Интересы России здесь заключаются в том, чтобы минимизировать свои экономические убытки.

Сотрудничество в рамках концепции следует поднять на уровень федеральной политики. При определении приоритетности отдельных направлений и проектов “северного измерения” необходимо отстаивать хозяйственные, социальные и иные потребности как российских северо-западных регионов, так и страны в целом. Чем полнее концепция и согласованные проекты отразят эти потребности, тем активнее и объемнее будет участие России в “северном измерении”.

Одной из наиболее острых проблем во взаимоотношениях России с ЕС является статус Калининградской области, которая после вступления Литвы и Польши в ЕС фактически станет российским анклавом внутри Евросоюза. Кстати, это вызов не только России, но и самому Евросоюзу. Только принятие эффективных согласованных мер поможет избежать негативных последствий для приграничных связей области, ее транзитного сообщения с Россией и, как следствие - для ее экономической и социальной ситуации.

Такие опасения не в полной мере разделяют на Западе. Министр иностранных дел Финляндии полагает, что “Калининград из российского анклава превращается в известном смысле в европейский анклав, а Балтийское море становится внутренним европейским морем с чрезвычайно динамичными перспективами развития торговли и сотрудничества” [см. Нюберг 2000]. Некоторые позитивные решения проблемы Калининградской области намечены, например, в совместном российско-литовском проекте, предложенном Евросоюзу в феврале 2000 г.

Мне представляется, что жизнеспособность и перспективность концепции “северного измерения” и принципа “позитивной взаимозависимости” напрямую связаны с тем, насколько ЕС и входящие в него государства в дальнейшем будут учитывать законные интересы России, равно как и с тем, насколько она сама готова идти на разумные уступки.

Еще одна важная проблема России - отсутствие четкого разграничения компетенции, в т.ч. в области внешнеэкономических связей и международного сотрудничества, между федеральным центром и субъектами Федерации [Авдеев 2000: 93]. К сожалению, этот вопрос пока остается неразрешенным в российском законодательстве. А ведь именно регионам должна принадлежать особая роль в реализации “северного измерения”. 
В этой ситуации первостепенное значение приобретают законы “О правовом статусе приграничных территорий” (с 1996 г. находящийся на рассмотрении Федерального Собрания) и “Об общих принципах трансграничного субрегионального сотрудничества с участием субъектов Российской Федерации” (который еще предстоит разработать). Важную роль призван сыграть и закон “О координации международных и внешнеэкономических связей субъектов Российской Федерации”, вступивший в силу в январе 1999 г. [Дерябин 2000: 70].

В России нет также правовой базы для выработки единой концепции трансграничного субрегионального сотрудничества, которое приобретает все больший размах (особенно это касается Карелии, имеющей общую границу с Евросоюзом). В 1999 г. правительство Республики Карелия совместно с властями трех приграничных областей восточной Финляндии выдвинуло идею создания “еврорегиона 'Карелия”, которая может быть использована Россией для реализации проекта “северного измерения”. Осуществление этой идеи способно открыть перспективные формы взаимодействия сопредельных территорий на внешних границах РФ и ЕС [Шлямин 1999: 30-32].

Стоит вспомнить и о тех возможностях, которые предоставляет России участие в Европейской рамочной конвенции о приграничном сотрудничестве территориальных сообществ и властей, являющейся в настоящее время основополагающим международно-правовым актом в области субрегионального сотрудничества. К сожалению, протокол о присоединении страны к этой конвенции до сих пор не ратифицирован.

Появление и быстрое развитие концепции “северного измерения” самым активным образом способствуют укреплению внешних связей ЕС в северной Европе, привносят новые элементы в его внешнюю политику и политику безопасности. Очевидна связь данной концепции с процессами в самом ЕС, с планами по его расширению, а также с его структурной, экономической, социальной и другой политикой. В настоящее время представляется несомненным, что “северное измерение” как часть общеевропейской политики придется учитывать при принятии решений в различных областях.

Некоторая, иногда излишняя осторожность Евросоюза в отношении России связана в основном с опасениями, что та “не сумеет откликнуться на открывающиеся перед ней возможности и будет все больше изолироваться вне рамок европейского развития” [см. Нюберг 2000]. “Северное измерение” дает нашей стране великолепный шанс постепенно интегрироваться в объединенное европейское пространство, но только от нее самой зависит, насколько успешным будет этот процесс.

Авдеев А.А. 2000. Международные и внешнеэкономические связи российских регионов. - Международная жизнь, № 4.

Аксенов М. 1994. Финляндия — наш традиционный торговый партнер. - Экономика и жизнь, № 27.

Верхняя Тулома как зеркало России. 2000. - За рубежом, № 7.

Воронов К.В. 1994. Россия и Северная Европа: новые ориентиры. - Мировая политика и международные отношения, № 1.

Дерябин Ю. 2000. Северное измерение и интерес России. - Современная Европа, № 2.

Дружинин П. 2000. Республика Карелия как пограничный и периферийный регион. - VI world congress. Tampere, 29.07 - 3.08. Abstracts.

Евро. 1999. № 11.

Коллективная стратегия ЕС в отношении России. 2000. - Современная Европа, № 1.

Крылов С.Б. 1996. Сотрудничество на Севере Европы. - Международная жизнь, № 9.

Люра М. 1998. Россия и Финляндия: партнеры в Новой Северной Европе. - Новое время, № 46.

Нюберг Р. 2000. Речь на 116-ой Конференции Бергердорфского форума. - Международная жизнь, № 4.

Романов С.Л. 1998. Межрегиональное сотрудничество на севере Европы. - Международная жизнь, № 3. 
Северное измерение России полезно. 1999. - Парламентская газета, 29.01.

Успенский Н.Н., Комиссаров С.Д. 1992. Новая страница сотрудничества в регионе Балтии (К началу деятельности Совета государств Балтийского моря). - Международная жизнь, № 11/12.

Шлямин В.Н. 1999. Растет роль субрегионального фактора на севере Европы. - Евро, № 12.

The Ministry for Foreign Affairs. Northern Dimension. Working Paper. 1998. Helsinki.

___ СЕИ предусматривает укрепление отношений США со странами Скандинавии, Балтии и северо-западными регионами России. В рамках этой программы определены шесть приоритетных направлений: развитие предпринимательства, сотрудничество правоохранительных органов, содействие созданию гражданского общества, энергетика, в т.ч. безопасность АЭС, экология и здравоохранение. 